\title{
ANTIMYCOTIC AND CYTOTOXICOLOGICAL POTENTIALS OF Acacia mearnsii De Wild. STEM BARK EXTRACT: IN VITRO ASSESSMENT
}

\author{
Olufunmiso O. Olajuyigbe ${ }^{* 1,2}$, Morenike O. Adeoye-Isijola ${ }^{1}$ and Roger M. Coopoosamy ${ }^{2}$ \\ ${ }^{1}$ Department of Microbiology, School of Sciences \& Technology, Babcock University, PMB \\ 4005, Ilisan Remo, Ogun State, Nigeria \\ ${ }^{2}$ Department of Nature Conservation, Mangosuthu University of Technology, Durban, \\ KwaZulu-Natal, South Africa \\ *Corresponding Author: Mobile: +2348101994655; E-mail: funmijuyigbe12@yahoo.com
}

(Received October 28th, 2018; Accepted December 12th, 2018)

\begin{abstract}
Despite using antimycotic drugs in the treatment of dermatomycoses as an age long practice, the fungicidal activities of indigenous plants on spores of dermatophytes from germinating in vitro need to be investigated further. In this study, methanol extract of Acacia mearnsii was assessed for its antifungal activity against dermatophytic pathogenic fungi by agar diffusion and broth dilution methods. The cytotoxicity activity of the extract was determined by the brine shrimp lethality assay. The study showed that the mean \pm standard deviation of the inhibition zones ranged between 13 and $24 \pm 0.58 \mathrm{mg} / \mathrm{ml}$ and the activity of the extract was concentration dependent. While the minimum inhibitory concentration (MIC) was $0.3125-2.5 \mathrm{mg} / \mathrm{ml}$, the minimum fungicidal concentration (MFC) values ranged between $0.3125 \mathrm{mg} / \mathrm{ml}$ and 5 $\mathrm{mg} / \mathrm{ml}$. The susceptibility of the yeast to the extract was more than those of the molds. The MIC of the yeasts ranged between 0.3125 and $1.25 \mathrm{mg} / \mathrm{ml}$ while those of the molds ranged between 0.625 and $2.5 \mathrm{mg} / \mathrm{ml}$. The mechanism of antibiosis showed that the extract was $7.69 \%$ fungistatic and $92.31 \%$ fungicidal wielding more killing effects on the fungi than potentiating their growth. The cytotoxicity assay showed that the crude methanolic extract with the $\mathrm{LC}_{50}$ being $101.59 \mu \mathrm{g} / \mathrm{ml}$ was pharmacologically active and nontoxic $\left(\mathrm{LC}_{50}>100 \mu \mathrm{g} / \mathrm{ml}\right)$. The antifungal activity of this plant can be exploited as an alternative or complementary means of treating fungal infections to eliminate fungal spread. The study further justified the folkloric use of A. mearnsii in the treatment of a variety of microbial infections.
\end{abstract}

Keywords: Acacia mearnsii, antifungal, cytotoxicity, fungicidal, mycotic infections

\section{INTRODUCTION}

Medicinal plants are a rich source of novel and powerful drugs (PONNUSAMY et al., 2010; YADAV et al., 2010). They manufacture an extremely disparate series of secondary metabolites which increase with commencement of drought, outbreak of fire and bacterial infection (TAIZ and ZEIGER, 2006). These secondary metabolites usually exhibit 
pharmacologically essential properties including cytotoxic, antimicrobial and antioxidant (OlajuYigbe and Afolayan, 2011; Joseph and Sujatha, 2011). Consequently, many in vitro studies on pharmacological relevance of medicinal plants have reported antifungal effects of many plants (PrUSTI et al., 2008; MoMTAZ and ABDOLlaHI, 2010). The effectiveness of these plants has been ascribed to the existence of a variety of phytochemicals.

In tropical countries, mycotic infections have become a disconcerted public health challenges (CHINELLI et al., 2003). Fungal infections have outstandingly increased in both developing and developed countries with the increase in the numbers of immunocompromised individuals in epidemic human immunodeficiency viral (HIV) infections (MEENA et al., 2009). While previously uncommon fungi which are difficult to manage and insidious opportunistic fungal infections caused by Aspergillus and Candida species are customarily accountable for the greater part of morbidity and mortality recorded in individuals undergoing haematopoetic stem cell transplantation (VISCOLI et al., 1999; GROLL and WALSH, 2001), the rising occurrence of fungal pathogens resistant to antifungal drugs has also become a great concern (MANIKANDAN et al., 2011). Consequently, while the administration of systemic drugs has become therapeutically inadequate due to increased level of toxicity and associated problems of residues in products intended for human consumption (ARAÚJO et al., 2009), many aboriginal plants species widely described is now being required for treatment of infections (LEE et al., 2007; VIGNESH et al., 2011). Being less toxic and not detrimental to human health (SATISH et al., 2009), bioactive compounds in plant extracts have become alternative to synthetic agents (KUMAR et al., 2010; OLAJUYIGBE et al., 2018).

Acacia mearnsii De Wild or Black Wattle, basically known as one of the world's highest yielding sources of high quality condensed tannin (YounG et al., 1986), is a tree with 20-30 tiny pale yellow globular inflorescence flowers. The dark brown to black pods are more or less straight, 5-10 cm long, 5-8 mm wide and strongly constricted between seeds. Although hundreds of plant species have been tested for antimicrobial properties, an immeasurable majority of plants, including A. mearnsii, have limited information on their therapeutic effectiveness. Considering plants as sources for antimicrobial drugs with reference to antifungal agents, this study was aimed at investigating the antifungal and cytotoxicity effects of the methanolic extract of $A$. mearnsii in vitro.

\section{MATERIALS AND METHODS}

\section{Collection of plant material}

The stem barks of A. mearnsii De Wild were collected from the plant growing in Nkonkobe municipality, Eastern Cape, South Africa. The plant was authenticated in the Department of Botany, University of Forth Hare and a voucher specimen (OLAJ Med 2010/01) was prepared and deposited in the Griffen Herbarium of the University.

\section{Extract preparation}

The bark sample was air-dried at room temperature, powdered in a mill (Christy Lab Mill, Christy and Norris Ltd; Process Engineers, Chelmsford, England) and stored in a sterile airtight container for further use. One hundred gram of the powdered sample was soaked in 500 $\mathrm{ml}$ of methanol by shaking vigorously for $72 \mathrm{~h}$ on Stuart Scientific Orbital Shaker, UK at high speed. The plant material was extracted for two successive times. The solvent was removed using a rotary evaporator set at the distillation temperature of the extracting solvent $\left(65^{\circ} \mathrm{C}\right)$ (Laborarota 4000 - efficient, Heldolph, Germany). The resulting crude extract was stored at - 
$20{ }^{\circ} \mathrm{C}$ until assayed. The extract was dissolved in methanol and made up with sterile distilled water to a concentration of $40 \mathrm{mg} / \mathrm{ml}$ stock solution from which serial dilutions and different concentrations were prepared.

\section{Test organisms}

The fungal isolates used in this study included Absidia corymbifera DSM-1144, Aspergillus flavus ATCC 9643, Aspergillus terreus DSM-826, Aspergillus niger ATCC 16404, Candida albicans ATCC 10231, Candida glabrata ATCC 2001, Candida krusei DSM-3433, Candida rugosa DSM-70761, Cryptococcus neoformans DSM-11959, Fusarium sporotrichioides DSM-62423, Penicillium notatum, Trichophyton mucoides ATCC 201382 and Trichophyton tonsurans ATCC 28942. These fungal isolates, maintained on potato dextrose agar and broth, were obtained from the Department of Biochemistry and Microbiology, University of Fort Hare, Alice, South Africa until they were used for the antifungal assays.

\section{Preparation of inocula}

The fungal inoculums were prepared according to the procedure of ABERKANE et al. (2002) with some modifications for the quantification of the fungi. Briefly, the inoculum of each isolate was prepared by first growing the fungus on potato dextrose agar for seven days. Thereafter, $1 \mathrm{~cm}^{2}$ of each sporulating culture dropped in sterile distilled water were then shaken for $5 \mathrm{~min}$ and appropriate dilutions were made to obtain an approximate concentration of $1 \times 10^{5}$ spores $/ \mathrm{ml}$ using spectrophotometer $\left(\mathrm{A}_{595} \mathrm{~nm}\right)$. In preparing $10^{4}$ colony forming units (CFU) per $\mu \mathrm{l}$ of the inoculums for the Candida spp., $1 \mathrm{ml}$ of each of the overnight candida broth cultures was added to $9 \mathrm{ml}$ of potato dextrose broth to yield.

\section{Antifungal assay by agar diffusion method (Inhibition zones)}

To determine the inhibition zones produced by the extract, $100 \mu 1$ of the adjusted fungal solutions, evenly spread with a sterile glass rod, was aseptically distributed on potato dextrose agar plates before allowing the culture to stand for $1 \mathrm{~h}$ on the laboratory bench. Agar wells were bored a $6 \mathrm{~mm}$ cork borer into the agar medium which were filled with $100 \mu \mathrm{l}$ of 10,20 and $40 \mathrm{mg} / \mathrm{ml}$ of the extract while spillage of the solution onto the agar surface was prevented. The culture plates were allowed to stand on the laboratory bench for $30 \mathrm{~min}$ to allow suitable diffusion of the extract before incubating at $27{ }^{\circ} \mathrm{C}$ for 3-7 days. Wells in blank potato dextrose agar plates containing 5\% methanol representing the final concentration of methanol in the test plates without the extract served as positive controls. After the incubation period, the antifungal effects were recorded by measuring the zones of inhibition in millimeter with a transparent meter rule. The antifungal assays were carried out in triplicates.

\section{Macrobroth dilution for minimum inhibitory concentration (MIC)}

Minimum inhibitory concentration (MIC) was determined by serial tube dilution technique (IWAKI et al., 2006; KHAN et al., 2007). Here, the plant extract was serially diluted to concentrations ranging between $0.1953 \mathrm{mg} / \mathrm{ml}$ and $40 \mathrm{mg} / \mathrm{ml}$ in double strength potato dextrose broth. Each broth concentration was inoculated with $100 \mu 1$ of the prepared fungal spores' solution before incubating at $27^{\circ} \mathrm{C}$ for 3-7 days. Two control tubes were included: one with spores and broth but no plant extract and one with broth and plant extract but no spores. The first tube in the series with no visible growth after incubation period was taken as the MIC. 


\section{Determination of minimum fungicidal concentrations (MFC)}

The MFC assays were carried out as described by CHEESBROUGH (2006). Here, extract-free potato dextrose agar plates were inoculated with one loopful of culture taken from each of the first five broth cultures that showed no growth and the first growth-containing tube in the MIC tubes. The MFC assay plates were incubated at $27^{\circ} \mathrm{C}$ for 3-5 days. After the incubation periods, the lowest concentration of the extract without visible fungal growth on agar was regarded as MFC values for this extract (IRKIN and KORUKLUOGLU, 2007). This observation was matched with the MIC test tube that did not show evidence of growth or spore germination for the fungi after five days of incubation.

\section{Brine shrimp lethality test}

The brine shrimp lethality test using the larvae of brine shrimps nauplii, Artemia salina L, was carried out using the standard procedure (MEYER et al., 1982; MCLAUGHLIN et al., 1998). From $1000 \mu \mathrm{g} / \mathrm{ml}$ of the extract prepared as stock solution, different concentrations $(0.9765-500 \mu \mathrm{g} / \mathrm{ml})$ of the extract were prepared by serial tube dilution technique in different vials. Ten nauplii were transferred into each vial using Pasteur pipettes. The brine shrimps were not fed because hatched brine shrimp can survive for up to $48 \mathrm{~h}$ without food (LEWIS, 1995) as they still feed on their yolk-sac (PELKA et al., 2000). The control vials were prepared using 5\% methanol alone and the experiment was replicated three times. After $24 \mathrm{~h}$ of incubation, the vials were examined, the numbers of survivors in each vial were counted and percentages of deaths were calculated. Larvae were considered dead if they did not exhibit any observable movement during several seconds of observation. The mortality percentage and $\mathrm{LC}_{50}$ (lethal concentration for $50 \%$ of the population) were determined using statistical analysis and the graph of Logarithm of concentration against percent lethality.

\section{Determination of mechanisms of antibiosis (fungicidal or fungistatic)}

To know whether the observed antifungal effects were fungicidal or fungistatic, the mechanism of antibiosis of the extract was calculated using the ratio of MFC/MIC or $\mathrm{MIC}_{\text {index }}$ as described by SHANMUGHAPRIYA et al. (2008). When the ratio of MFC/MIC was $\leq 2.0$, the extract was considered fungicidal or otherwise fungistatic. If the ratio is $\geq 16.0$, the extract was considered ineffective.

\section{RESULTS AND DISCUSSION}

Since the first step towards achieving effective treatment of fungal infection is the in vitro antifungal activity assay (TONA et al., 1998), the macrobroth dilution assay is an effective method (BARON et al., 1994) permitting direct contact between the fungal cells and the test extract. In this study, all the fungal isolates were highly susceptible to different concentrations of the methanol extract. With the exception of A. niger, C. krusei and A. corymbifera, all the fungal strains were inhibited by the lowest concentration $(10 \mathrm{mg} / \mathrm{ml})$ of the extract. At $20 \mathrm{mg} / \mathrm{ml}$, the mean \pm standard deviation of the inhibition zones ranged between $13 \pm 0.58$ and $21 \pm 0.58 \mathrm{mg} / \mathrm{ml}$. At the $40 \mathrm{mg} / \mathrm{ml}$, the mean \pm standard deviation ranged between $15.00 \pm 0.00$ and $24 \pm 0.58 \mathrm{mg} / \mathrm{ml}$. Generally, the mean inhibition zones of each fungi showed that the activity of the extract was concentration dependent (Table 1).

The MICs ranged between 0.3125 and $2.5 \mathrm{mg} / \mathrm{ml}$. With the exception of $C$. krusei, the MIC of other Candida strains was $0.3125 \mathrm{mg} / \mathrm{ml}$. While the MIC of the yeasts ranged between 0.3125 and $1.25 \mathrm{mg} / \mathrm{ml}$, those of the molds ranged between $0.625 \mathrm{mg} / \mathrm{ml}$ and $2.5 \mathrm{mg} / \mathrm{ml}$. The MFC values, ranging between 0.3125 and $5 \mathrm{mg} / \mathrm{ml}$, were similar or $2-4$ folds higher than the 
MIC values of the extract. The mechanism of antibiosis showed that the extract was $7.69 \%$ fungistatic and $92.31 \%$ fungicidal indicating that the extract has more killing effects on the fungi than potentiating their growth (Table 2).

Table 1. Antifungal activity of methanolic stem bark extract of $A$. mearnsii

\begin{tabular}{|c|c|c|c|}
\hline \multirow[b]{2}{*}{ Tested species/concentration } & \multicolumn{3}{|c|}{$\begin{array}{c}\text { Mean Zone of Inhibition } \\
\pm \text { Standard deviation }( \pm 1.00 \mathrm{~mm})\end{array}$} \\
\hline & $10 \mathrm{mg} / \mathrm{ml}$ & $20 \mathrm{mg} / \mathrm{ml}$ & $40 \mathrm{mg} / \mathrm{ml}$ \\
\hline A. niger ATCC 16404 & $0.00 \pm 0.00$ & $14.67 \pm 0.58$ & $17.00 \pm 1.00$ \\
\hline A. terreus DSM-826 & $12.67 \pm 0.58$ & $14.67 \pm 0.58$ & $18.33 \pm 0.58$ \\
\hline A. flavus ATCC 9643 & $12.00 \pm 0.00$ & $14.33 \pm 1.00$ & $15.00 \pm 0.00$ \\
\hline C. krusei DSM-3433 & $0.00 \pm 0.00$ & $12.67 \pm 0.58$ & $15.00 \pm 1.00$ \\
\hline C. rugosa DSM-70761 & $15.67 \pm 0.58$ & $18.67 \pm 0.58$ & $21.33 \pm 0.58$ \\
\hline C. albicans ATCC 10231 & $16.33 \pm 0.58$ & $16.33 \pm 0.58$ & $19.00 \pm 1.00$ \\
\hline C. glabrata ATCC 2001 & $12.67 \pm 0.58$ & $15.33 \pm 0.58$ & $18.00 \pm 0.00$ \\
\hline P. notatum & $13.00 \pm 0.00$ & $15.33 \pm 0.58$ & $17.33 \pm 0.58$ \\
\hline C. neoformans DSM-11959 & $14.00 \pm 1.00$ & $15.33 \pm 0.58$ & $17.33 \pm 0.58$ \\
\hline A. corymbifera DSM-1144 & $0.00 \pm 0.00$ & $17.00 \pm 0.00$ & $20.33 \pm 0.58$ \\
\hline F. sporotrichioides DSM-62423 & $18.00 \pm 0.00$ & $20.67 \pm 0.58$ & $23.67 \pm 0.58$ \\
\hline T. tonsurans ATCC 28942 & $15.00 \pm 0.00$ & $18.00 \pm 0.00$ & $19.67 \pm 0.58$ \\
\hline T. mucoides ATCC 201382 & $17.33 \pm 0.58$ & $19.67 \pm 0.58$ & $22.00 \pm 1.00$ \\
\hline
\end{tabular}

Table 2. Antifungal activity of methanolic extract of $A$. mearnsii

\begin{tabular}{lccc}
\hline & \multicolumn{3}{c}{ Inhibitory and fungicidal activities of $\boldsymbol{A}$. } \\
mearnsii \\
\cline { 2 - 4 } Tested species & MIC mg/ml & MFC mg/ml & MFC/MIC \\
\hline A. niger ATCC 16404 & 2.5 & 5 & 2 \\
A. terreus DSM-826 & 2.5 & 5 & 2 \\
A. flavus ATCC 9643 & 2.5 & 5 & 2 \\
C. krusei DSM-3433 & 1.25 & 2.5 & 2 \\
C. rugosa DSM-70761 & 0.3125 & 1.25 & 2 \\
C. albicans ATCC 10231 & 0.3125 & 1.25 & 4 \\
C. glabrata ATCC 2001 & 0.3125 & 0.625 & 2 \\
P. notatum & 2.5 & 5 & 2 \\
C. neoformans DSM-11959 & 0.3125 & 0.3125 & 1 \\
A. corymbifera DSM-1144 & 0.625 & 0.625 & 1 \\
F. sporotrichioides DSM-62423 & 0.625 & 0.625 & 1 \\
T. tonsurans ATCC 28942 & 0.625 & 2.5 & 2 \\
T. mucoides ATCC 201382 & 2.5 & 5 & 2 \\
\hline
\end{tabular}

By subjecting the brine shrimps to different concentrations of the extract, death of the brine shrimps was noticed in the experimental group but the control group remained unchanged over the same period of time. The number of surviving brine shrimps in each vial was counted and the results were noted. The percentage of death of the shrimp was calculated for every concentration of the test sample. The extract killed $6.7 \%$ of the brine shrimp at $31.25 \mu \mathrm{g} / \mathrm{ml}$ while $96.7 \%$ of the shrimps were killed at $500 \mu \mathrm{g} / \mathrm{ml}$ after $24 \mathrm{~h}$ incubation. The death rate of the brine shrimps increase with the increase in concentration of the extract as 
shown by a graph of Logarithm of concentrations versus percentage mortality presented as Figure 1. It is evident from the results of the brine shrimp lethality testing that the crude extract with the $\mathrm{LC}_{50}$ being $101.59 \mu \mathrm{g} / \mathrm{ml}$ had the highest $(96.7 \%)$ death percentage at 500 $\mu \mathrm{g} / \mathrm{ml}$.

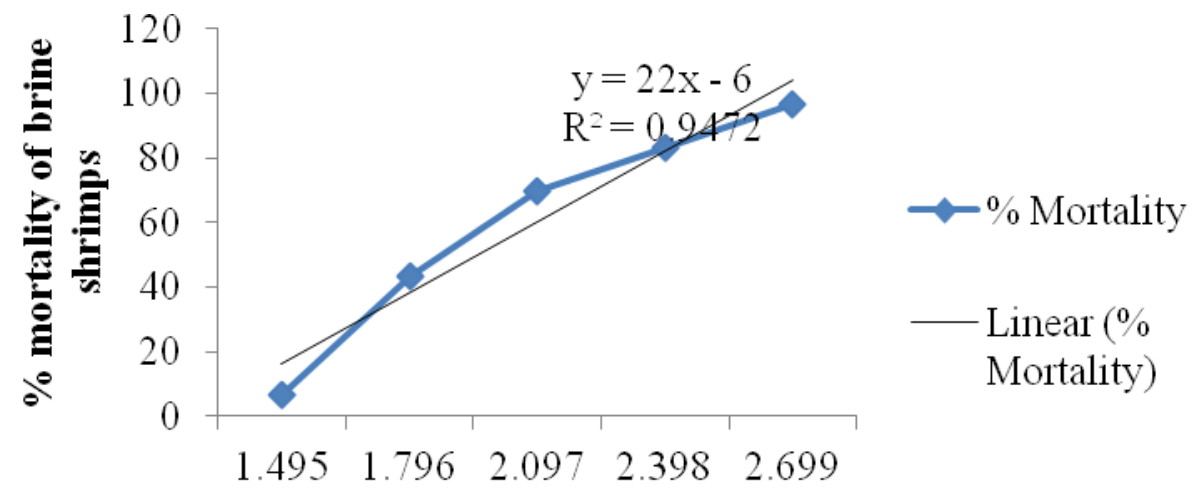

\section{Logarithm of concentrations}

Figure 1. Cytotoxic effect of methanolic stem bark extract of $A$. mearnsii on brine shrimps naupauli

The roles of fungi in pathogenic dermatophytic and mycotic infections have been enumerated in previous studies (FAN et al., 2008; DE TOLEDO et al., 2011) while the use of plant extracts is indicated as an alternative form of therapy for mycosis and candidiasis (LAZAREVIĆ et al., 2011). However, due to the rate of recurrence of fungal infections being on the rise (CAPOOR et al., 2005), microbial resistance (SIMONS et al., 2006), adamant nature of both cutaneous or superficial and systemic fungal infections and the toxicity often associated with many pharmacologically active antifungal agents, the need to explore alternative means of treating fungal infections with natural remedies having no toxicological side effects on human systems becomes extremely necessary.

Accordingly, several studies have shown the antifungal potentials vested in alcoholic extracts of several higher plants against fungal pathogens (SARFARAZ et al. 2002; MALABADI and KUMAR (2007). AMANLOUA et al. (2004) indicated that methanolic extracts of Satureja khuzestanica inhibited C. albicans and A. niger. MUSCHIETT et al. (2005) reported in vitro antifungal activities of 11 traditionally used Argentine medicinal plants against dermatophytes with microbroth dilution method. While dichloromethane extract of the resinous exudate from Baccharis grisebachii was reported active against Epidermophyton floccosum, Microsporum gypseum, Microsporum canis, T. rubrum and T. mentagrophytes (FERESIN et al., 2003), methanol extract of Plumbago zeylanica bark was inhibitory against T. mentagrophytes, $T$. simii, T. rubrum (SUBRAMONEY et al., 2003) and that of Myracrodruon urundeuva showed antifungal activity on Fusarium (SÁ et al., 2009). In this study, the antifungal activity exhibited by the methanolic extract of $A$. mearnsii agreed with previous reports indicating antifungal activities of many traditionally used medicinal plants and corroborated its folkloric use as indicated by SOMCHIT et al. (2003).

Although the antifungal activities of many medicinal plants have been investigated with lacks on their cytotoxicity potentials, some of the studied medicinal plants exhibited moderate to good cytotoxicity (RHAMAN et al., 2007). The brine shrimp lethality test is used to evaluate different pharmacological activities of natural remedies taking into account that pharmacology is simply toxicology at a lower dose. Since plant extracts are regarded as being mildly toxic if their lethal concentration for $50 \%\left(\mathrm{LC}_{50}\right)>30<100 \mu \mathrm{g} / \mathrm{ml}$ and non-toxic if their $\mathrm{LC}_{50}$ is greater than $100 \mu \mathrm{g} / \mathrm{ml}$ in the brine shrimp lethality assay (MosHI et al., 2010), it is 
evident that the methanol extract with the $\mathrm{LC}_{50}$ being $101.59 \mu \mathrm{g} / \mathrm{ml}$ was non toxic $\left(\mathrm{LC}_{50}>\right.$ $100 \mu \mathrm{g} / \mathrm{ml}$ ) and considerably active since extract with LC $_{50}$ lower than $250 \mu \mathrm{g} / \mathrm{ml}$ had earlier been considered considerably active by RIESER et al. (1996). Pharmacologically, the varied inhibitory and fungicidal activity exhibited by this extract against the different fungal isolates may be attributed to its toxicity level and the various phytochemicals present in the plant (OlaJuYigBe and Afolayan, 2011). Since it is important to investigate the fungicidal activity of potential chemotherapeutic agents to determine their ability to kill pathogens outright in clinical settings, the fungicidal and cytotoxicity activities of $A$. mearnsii may be valuable in treating serious dermal fungal infections especially when the host defense mechanisms are compromised.

\section{CONCLUSION}

This study indicates that $A$. mearnsii possess antifungal and cytotoxic properties in vitro and provides scientific basis for the use of this plant in folk medicine for the treatment of dermatophytic fungal infections. While the antifungal activity indicates that there are active compounds of significance, the cytotoxicological effect indicates that this plant is a potential source of a novel antifungal natural product that may be isolated and used in the treatment of skin infections. Further studies exploring the in vivo antifungal activities of this plant to establish its complete safety profile, isolate and characterize the active compounds, especially those having therapeutic indices, are required.

\section{Conflict of interest}

No potential conflict of interest relevant to this article was reported.

\section{References:}

[1] Aberkane, A., Cuenca-Estrella, M., Gomez-Lopez, A., Petrikkou, E., Mellado, E., Monzón, A., Rodriguez Tudela, J.L., THE EUROFUNG NETWORK. (2002): Comparative evaluation of two different methods of inoculum preparation for antifungal susceptibility testing of filamentous fungi. Journal of Antimicrobial Chemotherapy 50(5): 719-722. doi: 10.1093/jac/dkf187

[2] Sarfaraz A., Ansari, S.H., Porchezhian, E. (2002): Antifungal activity of alcoholic extracts of Zizyphus vulgaris and Acacia concinna. Hamdard Medicus 14/15: 42-45.

[3] Amanlou, M., Fazeli, M.R., Arvin, A., Amin, H.G., FArsam, H. (2004): Antimicrobial activity of crude methanolic extract of Satureja khuzestanica. Fitoterapia 75(7-8): 768-770. doi: 10.1016/j.fitote.2004.09.005

[4] Araújo, C.R., Miranda, K.C., Fernandes, O.F.L., Soares, A.J., Silva, M.R. (2009): In vitro susceptibility testing of dermatophytes isolated in Goiania, Brazil, against five antifungal agents by broth microdilution method. Revista do Instituto de Medicine Tropical de São Paulu 51(1): 9-12. doi: 10.1590/S0036-466520 09000100002

[5] Baron, E.J., Peterson, L.R., Finegold, S.M. (1994): Bailey and Scott's diagnostic Microbiology, $9^{\text {th }}$ Ed., Mosby-Year book, St. Louis. 
[6] Capoor, M.R., Nair, D., Deb, M., Verma. P.K., Srivastava, L., Aggarwal, P. (2005): Emergence of non-albicans Candida species and antifungal resistance in a tertiary care hospital. Japan Journal of Infectious Diseases 58(6): 344-348.

[7] Cheesbrough, M. (2006): District Laboratory Practice in Tropical Countries. ${ }^{\text {st }}$ Edn., Cambridge University Press, Cambridge, UK, pp. 434.

[8] Chinelli, P.A.V., Sofiatti, A.A., Nunes, R.S., Martings, J.E. (2003): Dermatophyte agents in the city of Sao Paulo, from 1992 to 2002. Revista do Instituto de Medicine Tropical de São Paulu 45(5): 259-263.

[9] de Toledo, C.E., Britta, E.A., Ceole, L.F., Silva, E.R., De Mello, J.C., Dias Filho, B.P., NAKamura, C.V., Ueda-Nakamura, T. (2011): Antimicrobial and cytotoxic activities of medicinal plants of the Brazilian cerrado, using Brazilian cachac, a as extractor liquid. Journal of Ethnopharmacology 133(2): 420-425. doi: 10. 1016/j.jep.2010.10.021

[10] FAN, S.R., LIU, X.P., LI, J.W. (2008): Clinical characteristics of vulvovaginal candidiasis and antifungal susceptibilities of Candida species isolates among patients in southern China from 2003 to 2006. Journal of Obstetrics and Gynaecology Research 34(4): 561-566. doi: 10.1111/j.1447-0756.2008.00817.x.

[11] Feresin, G.E., Tapia, A., Gimenez, A., Ravelo, A.G., Zacchino, S., Sortino, M., SCHMEDA-HiRSCHMANN G. (2003): Constituents of the Argentinian medicinal plant Baccharis grisebachii and their antimicrobial activity. Journal of Ethnopharmacology 89(1): 73-80.

[12] Groll, A.H., WALsh, T.J. (2001): Uncommon Opportunistic Fungi: New Nosocomial Threats. Clinical Microbiology and Infections 7(2): 8-24.

[13] IRKIN, R., KoruKLuOGLU, M. (2007): Control of Aspergillus niger with garlic, onion and leek extracts. African Journal of Biotechnology 6: 384-387.

[14] Iwaki, K., Koya-Miyata, S., Kohno, K., Ushio, S., Fukuda, S. (2006): Antimicrobial activity of Polygonum tinctorium Lour: Extract against oral pathogenic bacteria. Nature Medicine 60(2): 121-125. doi: 10.1007/s11418-005-0025-z

[15] JOSEPH, B., SUJATHA, S. (2011): Bioactive compounds and its autochthonous microbial activities of extract and clove oil (Syzygium aromaticum L.) on some food borne pathogens. Asian Journal of Biological Science 4(1): 35-43. doi: 10.3923/ajbs. 2011.35.43

[16] Khan, A., Rhaman, M., Islam, S. (2007): Antibacterial, antifungal and cytotoxic activities of Tuberous Roots of Amorphophallus campanulatus. Turkey Journal of Biology 31(3): 167-172.

[17] Kumar, D., Bhat, Z.A., Singh, P., Shah, M.Y., Bhujbal, S.S. (2010): Ailanthus excelsa Roxb. Is really a plant of Heaven. International Journal of Pharmacology 6(5): 535-550. doi: 10.3923/ijp.2010.535.550

[18] Lazarević, J.S., ĐorĐević, A.S., Zlatković, B.K., Radulović, N.S., Palić, R.M. (2011): Chemical composition and antioxidant and antimicrobial activities of essential oil of Allium sphaerocephalon L. subsp. sphaerocephalon (Liliaceae) inflorescences. Journal of Science Food and Agriculture 91(2): 322-329. doi: 10.1002/jsfa.4189.

[19] LEWIS, G.E. (1995): Testing the toxicity of extracts of Southern African plants using brine shrimp (Artemia salina). South African Journal of Science 91(8): 382-384.

[20] Malabadi, R.B., Kumar, S.V. (2007): Assessment of Antifungal Activity of Some Medicinal Plants. International Journal of Pharmacology 3(6): 499-504. doi: 10.3923/ ijp.2007.499.504 
[21] Manikandan, S., Ganesapandian, S., Singh, M., Sangeetha, N., Kumaraguru, A.K. (2011): Antimicrobial activity of seaweeds against multidrug resistant strains. International Journal of Pharmacology 7(4): 522-526. doi: 10.3923/ijp.2011.522.526

[22] MCLaughlin, J.L., Rogers, L.L. Anderson, J.E. (1998): The use of biological assays to evaluate the botanicals. Drug Information Journal 32(2): 513-524. doi: 10.1177/00 9286159803200223

[23] Meena, A.K., Kaur, R., Singh, B., Yadav, A.K., Singh, U., Sachan, A., Pal, B., RAO, M.M. (2009): Review on antifungal activities of Ayurvedic medicinal plants. Drug Invention Today 2(2): 146-148.

[24] Meyer, B.N., Ferrigni, N.R., Putnam, J.E., Jacobsen, L.B., Nichols, D.E., Melaughlin, J.L. (1982): Brine shrimp: A convenient general bioassay for active plant constituents. Planta Medica 45(5): 31-34. doi: 10.1055/s-2007-971236

[25] Momtaz, S., Abdollahi, M. (2010): An Update on Pharmacology of Satureja Species: from antioxidant, antimicrobial, antidiabetes and anti-hyperlipidemic to reproductive stimulation. International Journal Pharmacology 68(4): 346-353. doi: 10.3923/ijp.2010.346.353

[26] Moshi, M.J., Innocent, E., Magadula, J.J., Otieno, D.F., Weisheit, A., Mbabazi, P.K., Nondo, R.S.O. (2010): Brine Shrimp of some plants used as Traditional Medicine in Kagera Region, North West Tanzania. Tanzania Journal of Health Research 12(1): 63-67.

[27] Muschietti, L., Derita, M., Sülsen, V., De Dios Muñoz J., Ferraro, G., Zacchino, S., MARTINO, V. (2005): In vitro antifungal assay of traditional Argentine medicinal plants. Journal of Ethnopharmacology 102(2): 233-238. doi: 10.1016/j.jep. 2005.06.017

[28] Olajuyigbe, O.O., Afolayan, A.J. (2011): Phytochemical assessment and antioxidant activities of alcoholic and aqueous extracts of Acacia mearnsii De Wild. International Journal of Pharmacology 7(8): 856-861. doi: 10.3923/ijp.2011.856.861

[29] OLAJUYIGBE, O.O., ONIBUDO, T.E., COOPOOSAMY, R.M., ASHAFA, A.O.T., AFOLAYAN, A.J. (2018): Bioactive compounds and in vitro pharmacological effects of ethanol stem bark extracts of Trilepisium madagascriense DC. International Journal of Pharmacology 14(7): 901-912. DOI: 10.3923/ijp.2018.

[30] Pelka, M., Danzl, C., Distler, W., Petschelt, A. (2000): A new screening test for toxicity testing of dental materials. Journal of Dentistry 28: 341-345.

[31] Ponnusamy, S., Gnanaraj, W.E., Marimuthu @ Antonisamy, J., Selvakumar, V., Nelson, J. (2010): The effect of leaves of Clitoria ternatea Linn against the fish pathogens. Asian Pacific Journal Tropical Medicine 3(9): 723-726. doi: 10.1016/S 1995-7645(10)60173-3

[32] Prusti, A., Mishra, S.R., SAhoo, S., Mishra, S.K. (2008): Antibacterial activity of some Indian medicinal plants. Ethnobotanical Leaflets 12: 227-230.

[33] Rahman, M.M., Alam, A.H.M.K., SAdiK, G., Islam, M.R., KHONDKAR, P., Hossain, M.A., RASHID, M.A. (2007): Antimicrobial and cytotoxicity activities of Achyranthes ferruginea. Fitoterapia 78(3): 260-262. doi: 10.1016/j.fitote.2006.12.003

[34] Rieser, M.J., Gu, Z.M., Fang, X.P., Zeng, L., WoOd, K.V., McLaughlin, J.L. (1996): Five novel mono-tetrahydrofuran ring acetogenins from the seeds of Annona muricata. Journal of Natural Products 59(2): 100-108. doi: 10.1021/np960037q

[35] SÁ, R.A., Argolo, A.C.C., Napoleao, T.H., Gomes, F.S., Santos, N.D.L., Melo, C.M.L., Albuquerque, A.C., XAvier, H.S., Coelho, L.C.B.B., Bieber, L.W., PAiva, 
P.M.G. (2009): Antioxidant, Fusarium growth inhibition and Nasutitermes corniger repellent activities of secondary metabolites from Myracrodruon urundeuva heartwood. International Biodeterioration and Biodegradation 63(4): 470-477. doi: 10.1016/j.ibiod.2009.01.002

[36] Satish, S., RaghavendRA, M.P., Raveesha, K.A. (2009): Antifungal potentiality of some plant extracts against Fusarium sp. Archives of Phytopathology and Plant Protection 42(7): 618-625. doi: 10.1080/03235400701287578

[37] Shanmughapriya, S.A., Manilal, A., Sujith, S., Selvin, J., Kiran, G.S., NATARAJASEENIVASAN, K. (2008): Antimicrobial activity of seaweeds extracts against multi-resistant pathogens. Annals of Microbiology 58(3): 535-541.

[38] Somchit, M.N., ReEzal, I., NuR, I.E., MutaliB, A.R. (2003): In vitro antimicrobial activity of ethanol and water extracts of Cassia alata. Journal of Ethnopharmacology 84(1): 1-4.

[39] Subramoney, S., Van Vuuren, S.F., Viljoen, A.M., Demirci, B., Baser, K.H.C. (2003): Antimicrobial properties and geographical variation in essential oil composition of fever tea Lippia javanica (Verbenaceae). ISE Newsletter 3: 1-17.

[40] LeE, S.O., Park, I.K., ChoI, G.J., Lim, H.K., Jang, K.S., ChO, K.Y., Shin, S.C., Kim, J.C. (2007): Fumigant activity of essential oils and components of Illicium verum and Schizonepeta tenuifolia against Botrytis cinerea and Colletotrichum gloeosporioides. Journal of Microbiology and Biotechnology 17(9): 1568-1572.

[41] TAIZ, L., ZEIGER, E. (2006): Plant Physiology, $4^{\text {th }}$ Edition, Sinauer Associates Inc., Publishers, Sunderland, Massachusetts, USA. pp 764. ISBN 0-87893-856-7.

[42] Tona, L., Kambu, K., Ngimbi, N., Cimanga, K., VlietincK, A.J. (1998): Antiamoebic and phytochemical screening of some Congolese medicinal plants. Journal of Ethnopharmacology 61(1): 57-65.

[43] Simons, V., Morrissey, J.P., Latijnhouwers, M., Csukai, M., Cleaver, A., YArrow, C., Osbourn, A. (2006): Dual effect of plant steroidal alkaloids on Saccharomyces cerevisiae. Antimicrobial Agents and Chemotherapy 50(8): 27322740. doi: 10.1128/AAC.00289-06

[44] Vignesh, S., RajA, A., James, R.A. (2011): Marine Drugs: Implication and Future Studies. International Journal of Pharmacology 7(1): 22-30. doi: 10.3923/ ijp.2011.22.30

[45] Viscoli, C., Girmenia, C., Marinus, A., Collette, L., Martino, P., Vandercam, B., Doyen, C., Lebeau, B., Spence, D., Kromery, V., De Pauw, B., Meunier, F. (1999): Candidemia in cancer patients: a prospective, multicenter surveillance study by the Invasive Fungal Infection Group (IFIG) of the European Organization for Research and Treatment of Cancer (EORTC). Clinical Infectious Diseases 28(5): 1071-1079. doi: 10.1086/514731

[46] Yadav, S., Jalalpure, S.S., SAini, P. (2010): Phytochemical screening of various extracts of stem bark of Bauhinia racemosa plant. International Journal of Pharmaceutical Research and Development 2(5): 1-8.

[47] Young, D.A., FerreirA, D., RouX, D.G. (1986): Stereochemistry and dynamic behavior of some synthetic 'angular' profisetinidin tetraflavonoid derivatives. Journal of Polymer Science Part A: Polymer Chemistry 24: 835-849. 